\title{
Trade unions in Slovenia: historical development and the current situation
}

\begin{abstract}
Slovenian trade unions - after the changes in the early 1990s and then a period of stabilisation at relatively high levels of density which lasted for more than a decade - have, in the second half of the last decade, and in accordance with the gradual, irreversible long-term changes in the employment structure and the recent contextual pressures, started to decline rapidly. We have found that the intensity of this change, which started to occur when Slovenia entered the EU, is comparable to the massive changes of the early 1990s. Analysis shows us that, within just a few years, the trade union density rate dropped from 40 per cent to less than 30 . The share of unionised blue-collar workers is declining relatively rapidly. Unionisation within public services is stable and/or growing, but not intensively enough to substitute for losses in manufacturing industry. In the concluding part of the article we try to offer - in a sketchy, stylised manner - some explanations for this quite dramatic, unfavourable trend, which have their roots in the twin aims of Slovenia's transition.
\end{abstract}

Keywords: Trade unions, representativeness, trade union density rate, confederations, strikes, public protests, EU accession, transition, competitive corporatism, incomes policies, intensification of work, wage restraint, union role

Introduction

Within the former Yugoslav system, the official union already had a sort of competition at the micro-level, where workers' councils frequently fulfilled classical union roles and functions which the official unions did not cover. Contemporary surveys, for instance, revealed that members of workers' councils were systematically more prone to striking than were trade union officials within companies (Arzenšek, 1984).

During the juncture period (in the early phase of the transition), when the workers' councils started to lose power, trade unions began to take over functions which, in the previous system, had been performed by the councils. Before that, trade union membership in Slovenia had already started to decrease, reaching a density rate of approximately 70 per cent in the late 1980 s. This early, spontaneous abolition of obligatory unionisation was tacitly recognised by the contemporary 'communist', but strongly reform-oriented authorities. This liberalisation was followed by trade union pluralisation, which then forced unions to compete for membership and to accommodate themselves to workers' demands. The result was that workers did not massively abandon unions when the transformational depression was reaching its peak, obviously under- 
standing that they were renewed and/or new organisations which were able to protect their vital interests.

\section{Trade union pluralisation}

Political pluralisation was in full swing in the late 1980s, reaching a qualitative turning point in 1990 when the first parliamentary elections were held. This major change of the system revealed that the Slovenian electoral body was almost equally divided into a conservative part on the one hand, and a liberal and social-democratic part on the other. According to this basic split, at the beginning of the transition two main clusters of political parties were formed: the cluster of the new anti-communist parties, with a more conservative orientation; and a cluster of old, reformed parties, which were more liberal and social-democratically oriented (Fink-Hafner and Krašovec, 2004: 15).

This early cleavage on the political scene was connected to the contemporary rapid re-organisation and pluralisation of the trade union scene. At the beginning of that process, a strong political polarisation within the trade union scene occurred, when the most intensive ideological and political conflicts broke out between ZSSS and KNSS. KNSS was tightly connected to the new, anti-communist Social-Democratic Party; while the old, reformed ZSSS was connected to the Associated List of Social Democrats (ZLSD), the reformed communists (today, the Social Democrats). Both ZSSS and KNSS were the strongest unions at that time, their connection to opposing political camps implied strong ideological and political divides within the trade union scene.

In the early phase of the transition, ZSSS was also faced with a serious internal crisis when some regional and sector organisations separated from the former single 'communist' (ZSS) union. These separations were partially caused by internal interest constellations within ZSS, but they were also fuelled by internal conflicts within the ZSS leadership, as well as by personal conflicts among the potential new leaders of the then-reforming ZSS.

During the period of the prevalence of left-centre coalitions (1992-2004), when trade unions focused on collective bargaining and the formation of the Slovenian social market economy, the former cleavages - both ideological (between ZSSS and KNSS), as well as organisational (between ZSSS and the new, smaller confederations that separated from ZSSS) - practically vanished. Real, substantive and interest-related differences between different segments of the workforce became more important. Accordingly, interest fragmentation, which had previously been covered up, i.e. was less visible, because of the political and ideological divides, started to occur. In addition to that, a gradually-changing employment structure, with a growing share of employees in public services, induced new interest splits and fragmentations between and within the private as well as the public sector.

The tendency towards fragmentation within the Slovenian trade union scene is strong. Not only has it been caused by splits between sectors and re-structurings, but also by the tradition of strong employee identification with their local communities and companies. 
This tendency towards trade union interest fragmentation was significantly reinforced by the law on trade union representativeness from 1993. According to this, any group of people consisting of only a few people could form a trade union. The formal requirement is the internal statute of the union, which has to be presented to the state agency (the Ministry of Labour). The agency then officially recognises the union as a legal entity/agency. Thresholds or other criteria are not defined. The minimum condition for the representativeness of a union confederation at the national level (in collective bargaining as well as within tripartite concertation processes) are at least two sectoral (or industry branch) affiliates that cover at least 10 per cent of employees from their sector. One autonomous sectoral national union organisation (which is not included in a confederation) can establish representativeness if it has at least 15 per cent coverage within a sector.

When justifying their representativeness, unions are obliged to produce for the authorities a signed membership list confirming the fulfilment of these conditions. Once confirmed as representative organisations, they then retain that status irrespective of subsequent membership-related changes. Theoretically, it is possible for a union which had acquired the status of representative organisation, and was registered as such, to lose members and then drop beneath the threshold while nevertheless keeping its representative status.

\section{Strikes and public protests}

During the juncture period (1988-1992), in spite of a transformational depression, Slovenia was faced with a quite dramatic strike wave.

Soon after the most critical phase, when the ten-day war from 1991 was over and the new independent state had already been formed, in 1992 - when the depression was at its lowest point - a relatively strong wave of strikes emerged. This was a sort of continuation of the process that had started within the former regime in 1987, when strikes began to occur in all parts of former Yugoslavia on a significantly more frequent basis than before. In 1992, there were almost two hundred strikes in Slovenia. In that year, the average strike included 372 participants while the number of working days lost per 1000 employees was 189 (Stanojević and Vrhovec, 2001). This strike wave, which was concentrated in labour intensive sectors of the economy - and precisely in those which were mostly affected by the disintegration of the former Yugoslav market - culminated in the same year in a large general warning strike, albeit that this lasted only a few hours. This massive action, which was organised by ZSSS, was a reaction to the announcement of a period of radical wage restraint when - in the context of high inflation - the government of the time decided to freeze wages.

The strike wave and the general strike had a particularly strong impact on the subsequent formation of the system of industrial relations in Slovenia. The second, centreleft government, formed after the 1992 elections, decided to include unions in the wage moderation process as a particular result of the strikes. This clearly demonstrated the mobilising power of the trade unions and their inclusion implied a wider involvement of unions in the formation of systemic laws. The outcome was the preservation of the relatively-developed Slovenian welfare state. 
In the late $1990 \mathrm{~s}$, when the strike rate in manufacturing industry had started to decline, a new - this time less intensive - wave of strikes occurred in the public sector.

At the end of the 1990s, the strike frequency calmed down, being substituted by a growing number of massive rallies, mostly organised by ZSSS. The most important was the large winter rally of 2005, when a mass of 40000 people gathered in the central square in Ljubljana to protest against the government's intention to radicalise the already-existing trend of neo-liberal reforms. In the context of a deteriorated social dialogue, as well as of the institutions of social partnership, both of which were totally incompatible with the proposed neo-liberal agenda, the rally immediately caused a significant decline of public support for the government; it hindered the planned reforms and enabled the at least partial renewal of social partnership institutions and functions.

Trade union density: gradual decrease in the 1990s and signs of a recent steep decline

The main source of the relatively reliable data concerning general trade union density rates in Slovenia are the surveys that have been systematically conducted during the last two decades by PORC. ${ }^{1}$ According to these data, the general trade union density rate (the share of the unionised workforce within the total labour force, i.e. within the sum of employed and unemployed persons) declined from an initial 66.5 per cent in 1991 to a level of 26.6 per cent in 2008.

Table 1 - Trade union density rates in Slovenia (1991-2008)

\begin{tabular}{|l|l|l|l|l|l|l|l|l|l|l|l|l|l|}
\hline $\mathbf{9 1 / 2}$ & $\mathbf{9 4 / 2}$ & $\mathbf{9 5 / 1}$ & $\mathbf{9 6 / 1}$ & $\mathbf{9 7 / 3}$ & $\mathbf{9 8 / 1}$ & $\mathbf{9 9 / 4}$ & $\mathbf{0 0 / 1}$ & $\mathbf{0 1 / 2}$ & $\mathbf{0 2 / 1}$ & $\mathbf{0 3 / 1}$ & $\mathbf{0 5 / 1}$ & $\mathbf{0 6 / 1}$ & $\mathbf{0 8 / 2}$ \\
\hline 66.5 & 60.2 & 50.4 & 48.8 & 44.1 & 42.7 & 40.4 & 41.6 & 40.8 & 44.6 & 43.7 & 37.1 & 31.4 & 26.6 \\
\hline
\end{tabular}

Source: PORC

It was suggested earlier that, during the late 1980s and early 1990s, when the trade union scene pluralised in the context of large systemic changes and the threatening escalation of the transformation depression, the high unionisation rate of 60-70 per cent of the late 1980s did not drop significantly at all. In the mid 1990s, the rate decreased by twenty percentage points and was then at a level of approximately forty per cent for a decade or so. From 2005, PORC surveys revealed a new, relatively steep membership decline: according to the 2005 survey, the general trade union density rate was 37.1 per cent but, just three years later, it had declined to 26.6 per cent.

Obviously, according to recent PORC surveys, Slovenian trade unions were exposed during 2005 to 2008 to probably the most dramatic membership decline and restructuring in their recent history. This decline is comparable, and even more intensive, to that of the beginning of the 1990s when Slovenia was faced with a dramatic economic crisis and large-scale systemic change. In contrast, the recent decline occurred during

1 PORC is a research unit of the Institute of Social Sciences at the Faculty of Social Sciences, University of Ljubljana. 
the years of economic prosperity and Slovenia's full integration into the EU and the Euro zone.

From a density rate of 43.7 per cent in 2003 , which had been stable at that level since the second half of the $1990 \mathrm{~s}$, the rate declined to a level of 26.6 per cent in 2008 . This represented a decline of seventeen percentage points in the density rate - or, in absolute terms, a decline from 420000 to 280000 members within a period of only five years. Between 2003 and 2008, Slovenian trade unions collectively lost one-third of their membership.

\section{The major trade union confederations}

Currently, there are seven trade union confederations in Slovenia: ZSSS, KNSS, Pergam, KS-90, Alternativa, Solidarnost and KSJS. ZSSS, KNSS, Pergam and KS-90 were formed at the beginning of the transition; Alternativa, Solidarnost and KSJS were formed later, during the last decade.

According to evidence based on PORC survey data, among these seven confederations the largest are ZSSS and KSJS: ZSSS covers more than one-half and KSJS almost one-quarter of total union membership in Slovenia.

\section{Zveza svobodnih sindikatov Slovenije (ZSSS; Association of Free Trade Unions of Slovenia)}

ZSSS is the largest and most influential trade union confederation in Slovenia. It was founded at its first congress, held in Ljubljana on 7 April 1990. ZSSS is the successor to the old Association of Trade Unions of Slovenia (ZSS). The result of this legacy is that it could be formally categorised as a case of an 'old reformed' union, similar to the successors of the old unions in other 'post-communist' countries.

At the beginning of the transition, ZSSS used to have a significant advantage when compared to newly-formed unions. This advantage stemmed from the inherited organisational infrastructure and other resources which were established and accumulated during the former 'real-socialist' regime. This advantage was significant, but it did not guarantee the confederation's survival. The key feature which enabled ZSSS to survive was its early turn towards workers' protection. Thanks to this early strategic reorientation, which was partially endogenous and partially caused by growing pluralism and competition within the trade union scene, ZSSS was relatively successful in articulating (blue-collar) workers' interests. It focused especially on the massive segment of those workers from industries which were, at the time, losing former domestic (Yugoslav) markets. These workers were the main source of the impressive mobilising power manifested by ZSSS in 1992, when the transformation depression hit its nadir in Slovenia. From that point on, ZSSS strongly influenced the development of social protection policies and measures which assured significant support to the survival of the welfare state during Slovenian 'post-communism' i.e. the transition to the market economy.

ZSSS remains primarily anchored in traditional industrial sectors; it is still mostly a union of blue-collar workers. It inherited and then developed an organisational structure consisting of the 'capillary' segment of shop floor organisations as well as sectoral and territorial organisations. At the level of the territorial (i.e. regional) organisations, 
ZSSS members can obtain professional legal advice and support on labour issues, which is provided free of charge.

ZSSS is a relatively centralised organisation, with a strong influence on the part of the confederation's leaders and the leaders of its main affiliates. The centre regularly participates in the work of the Economic and Social Council (ESC), i.e. it is systematically involved in interactions with the other social partners and in the corresponding public policy formulation process. This is an important external, additional source of power for the centre, which legitimises not only the role of ZSSS in society but which also induces and supports internal integration and centralisation.

During the 1990s, ZSSS systematically covered more than 50 per cent of the unionised workforce in Slovenia. Just like the majority of the other Slovenian unions, however, ZSSS was losing membership gradually while its share of the total unionised workforce has also slightly declined over the last two decades. In membership terms, its absolute prevalence on the Slovenian trade union scene is definitely not as stable and as persuasive as it used to be.

The most recent figure concerning ZSSS membership, which could be reconstructed from PORC data and interviews with ZSSS representatives (conducted on $31 \mathrm{March}$ 2009), is 155 000. ZSSS has 21 affiliates. Among them is SKEI - the Trade Union of Metal and Electrical Workers of Slovenia, which is the largest. In 2009, according to its President, it has something like close to 40000 members. This is approximately one-quarter of the total ZSSS membership.

Table 2 - Membership of ZSSS and its main affiliates (2009)

\begin{tabular}{|l|l|}
\hline SKEI & 38000 \\
\hline KNG & 11000 \\
\hline Other (19) affiliates & 56000 \\
\hline ZSSS (total) & $155000^{*}$ \\
\hline
\end{tabular}

* Estimate

Konfederacija sindikatov javnega sektorja (KSJS; Confederation of Public Sector Trade Unions)

KSJS is the second largest trade union confederation in Slovenia. It was established at the beginning of 2006, when SVIZ (the Education, Science and Culture Trade Union of Slovenia) amalgamated with four other unions from the public services sector to form a new confederation. This most important amalgamation within the Slovenian trade union scene after 1990 emerged only a few months after the large trade union rally in November 2005, when practically all Slovenian unions jointly struggled against the then government's intended radical neo-liberal reforms. At the time, the government also announced the formation of a new uniform salary system for public sector employees. This basically induced the rapid formation of a new union confederation within the public sector - definitely a most important, and probably entirely unintended, side-effect of the government's initiative concerning the new salary system. 
After the amalgamation, the new confederation became a full member of the Economic and Social Council (ESSS): beforehand, the fragmented public unions had not been represented on this body. Along with its membership of the ESSS, KSJS is also represented on the steering committee of the pension fund for public servants.

KSJS argues for strong public sector services and protection of employees in the public sector. Its relationship with other confederations and sectoral unions are mostly co-operative, but some tensions between KSJS and some of the other national union organisations from the public sector occasionally arise - mostly concerning the representativeness issues and payment disparities within the public sector. When the main, grandstand policy issues, like healthcare and pensions reform, are on the agenda, KSJS normally co-operates with all the other confederations.

KSJS is primarily organised into sectors. Membership is formally organised on the level of public agencies within sectors, such as education and healthcare, but the sectoral organisations are more important and it is also these with which the members mostly identify. Concerning the new confederation, its main authority is concentrated at the SVIZ headquarters, which formally partially overlaps with the KSJS leadership.

KSJS has between 60000 and 70000 members distributed among seven national union affiliates. The largest are SVIZ (Education, Science and Cultural Trade Union of Slovenia; and SZSVS (Trade Union of Health and Social Services of Slovenia). In terms of membership the former, with its almost 40000 members, is comparable to SKEI - a key sector organisation within ZSSS. SZSVS has 18000 members (on the basis of PORC figures and those from KSJS itself).

\section{Recent membership distribution among confederations}

The PORC survey conducted in 2008 enables us to provide a rough estimate of the membership distribution among the main Slovenian trade union confederations.

In terms of membership, the largest is ZSSS, which has between 150000 and 160000 members. The second most important confederation is KSJS, which has 60000 to 70000 members.

In formal terms, these two major confederations, together with the other two smaller confederations (KNSS and Pergam) cover almost 90 per cent of the total unionised population in Slovenia.

The remaining less than 10 per cent, i.e. approximately 24000 unionised workforce which are not covered by these four confederations, are mostly members of some autonomous company unions, as well as the smaller autonomous white-collar sector and/ or occupational unions (for instance the medical doctors' union FIDES) and the two small confederations (Alternativa and Solidarnost).

The high formal inclusion of the unionised workforce in the major confederations has actually only been typical of the most recent period, i.e. after 2006 when KSJS was formed. Before that, roughly 30 per cent of total union membership was not covered by the confederations. Nevertheless, according to PORC data, this typically high and growing formal concentration of trade union membership within the major confederations hides a significant counter-tendency - a quite strong trend of fragmentation within these formally associated structures. The data suggests that an important part of 
total trade union membership, formally included in the major confederations, does not identify with the confederations. The PORC survey from 2008, for instance, reveals that 20 per cent of respondents, who are probably for the most part formally included indirectly in ZSSS, primarily identify with their company unions. In the case of KSJS, its formal members are mostly identified with the sector unions - the affiliates of KSJS.

\section{Concluding remarks: the causes of the decline}

This analysis has revealed three major changes that have marked Slovenian trade unions during the last two decades: firstly, a gradual decline in the trade union density rate, followed by a more rapid one in the second half of the last decade; secondly, a changing membership structure marked by the growing share of unionisation taken by the public sector; and thirdly, increased levels of interest fragmentation between and within union confederations.

Most of these changes are common to the unfavourable developments that emerged within different national environments (and trade union movements) during the last three decades. The Slovenian peculiarity can be seen in the steep, atypical decline that occurred between 2005 and 2008. What are the possible explanations for this quite dramatic and unfavourable change?

In the early 1990s, the neo-corporative industrial relations system, similar to those that developed in some European countries in the decades after the Second World War, was formed in Slovenia. The system functioned without any major visible disturbances during the accession process.

Basically, the system was focused on the realisation of the two major aims of the Slovenian transition: accession to the EU and the Economic and Monetary Union regime on the one hand; and, on the other, the assurance of job and wage security, together with all the basic features of the welfare system, for the core workforce. Being framed by the demands of the EMU regime, Slovenian neo-corporatism could not but acquire the features of 'competitive corporatism' (Rhodes, 1997), i.e. the 'competitive solidarity system' (Streeck, 1999). One of its main features was the policy of wage restraint. The Slovenian trade unions were strongly involved in the formation of that system.

Slovenia's accommodation to the EU and the EMU regime, being framed by the functioning 'competitive corporatism' structure, also implied a sort of very gradual, but systematic, change at the system's micro level, i.e. within company organisations. The changes were primarily focused on tighter managerial control, as well as on time structure transformations (working time extension, shift work, etc.). Accordingly, contemporary comparative research studies revealed that the accession process, and the corresponding full inclusion of the Slovenian export economy in the European market(s), implied a gradual increase in the intensification of work and thus an increased level of pressure on the labour force (FEWCS, 2007; Svetlik and Ilič, 2006). Such pressure was systematically combined with the usage of the Slovenian neo-corporative restrictive incomes policies mentioned above.

In the early years of the 2000s, the EU was, in comparison to the early 1990s, significantly changed. The EU/EMU system, to which Slovenia accessed in the middle of that decade, did not fit the prevailing perception of social Europe, which had strongly 
motivated the processes of Europeanisation at the beginning of the Slovenian transition. Workers' patience concerning the more than decade-long and systematic period of work intensification and a policy of wage restraint, two of the perhaps less exposed but nevertheless key features of 'competitive corporatism', was mostly supported and generated by high expectations regarding the inclusion of Slovenia in the EU.

Understandably, the shock caused by inclusion in the new (and, in the meantime, changed) European system was quite intensive. In the second half of the decade, the shock was further intensified by the occurrence of some additional and mutually-interconnected factors.

An important contextual change for workers and unions was the electoral victory of right (and centre)-oriented parties in 2004, i.e. the year when Slovenia became a full member of the EU. The new government launched radical neo-liberal reforms at the beginning of its 2004-2008 mandate, as has been mentioned already. In the centre of these reforms was a flat tax rate; the second wave of privatisation was a less visible but an equal, if not even more important, part of that programme. The unions opposed these reforms and became embroiled in a conflict with the government, which culminated in late 2005, when they enjoyed massive public support. Workers, who had already been exposed to growing pressures during the accession process, strongly supported the unions in the defence of Social Slovenia, and namely the defence of the perception of Social Europe, which had sustained their patience during the 1990s.

The unions' opposition undoubtedly hindered some of the intended changes (indeed, the flat tax rate was not introduced). In the aftermath of the conflict, the public support for the government decreased so dramatically that it could not recover and, accordingly, the centre-right suffered defeat in the 2008 elections.

In spite of the massive political conflict from 2005, the general trend of these incrementally escalating pressures on workers over the decade was not at all restrained: the pressures simply became a part of the normal functioning of 'competitive corporatism' - a system in which unions had been co-authors of that type of 'normal working'.

In the second half of this last decade, Slovenian workers were faced with two additional, and completely new, sources of growing pressure. The first resulted from the introduction of the fixed exchange rate, prior to the inclusion of Slovenia into the euro zone (in 2007). Managers' responses to this new shock implied an additional intensification of work and a tightening of the concept of control within companies. The second source of this pressure was the new wave of privatisation. This also implied more work for the same and/or restrained level of payment; and, later, when the wave of bankruptcies occurred (within the context of the financial crisis), in quite numerous cases more work without any kind of payment at all.

The results of the transition and the accession process have been extremely disappointing for workers. Trade unions' political conflict with the government was not sufficient to neutralise the basic expectations of workers, which thus remained unfulfilled (Meardi, 2012). Their expectations were simply too high. Unions, together with all the major political players, paid a painful price for the massive disillusionment that resulted. Accordingly, rapid de-unionisation was unavoidable. 
In conclusion, all of the outlined changes on the Slovenian trade union scene have implied a weakening of the mobilisation capacity of Slovenian trade unions. This capacity is significantly lower today than it was in the 1990s. Accordingly, the Slovenian model of industrial relations has been exposed to correspondingly intensive changes. In spite of this, unions are still relevant players on the Slovenian industrial relations scene. Similar to unions in some other western European countries, they are still an undoubtedly important source of legitimisation for weak governments. However, it seems that their role and influence is today much more limited to the agenda of concession bargaining than it used to be in the past.

\section{References}

Arzenšek, V (1984) Struktura in pokret Beograd: Institut društvenih nauka, Univerzitet u Beogradu.

FEWCS (2007) The Fourth European Working Conditions Survey Dublin: European Foundation for the Improvement of Living and Working Conditions.

Fink-Hafner, Danica and Alenka Krašovec (2004) Ideološko-politične cepitve v slovenski strankarski areni po letu 1989 mednarodna konferenca 'Razvoj političnega pluralizma in strankarskih aren v Sloveniji in Bosni in Hercegovini v obdobju 1989-2003'.

Meardi, G (2012) Social Failures of EU Enlargement: A Case of Workers Voting with their Feet London: Routledge.

Rhodes, M (1997) 'Globalisation, Labour Markets and Welfare States: A Future of 'Competitive Corporatism'?' in: M. Rhodes and Y. Mény (Eds.) The Future of European Welfare: A New Social Contract? London: Macmillan, pp. 178-203.

Stanojević, M and P. Vrhovec (2001) 'Industrial conflict in Slovenia' South-East Europe Review 4(1): 29-37.

Streeck, W (1999) Competitive solidarity: rethinking the European Social Model MPIfG Working Paper 1999/8, Cologne: Max Planck Institute for the Study of Societies.

Svetlik, I and B. Ilič (Eds.) (2006) HRM's Contribution to Hard Work, A Comparative Analysis of Human Resource Management Bern: Peter Lang.

\section{Abbreviations}

ESC - Economic and Social Council / Ekonomsko-socialni Svet (ESSS)

KS-90 - Konfederacija sindikatov 90 / Trade Union Confederation 90

KNSS - Konfederacija novih sindikatov Slovenije / Independence, Confederation of New Slovenian Trade Unions

KSJS - Konfederacija sindikatov javnega sektorja / Public Sector Trade Unions

LDS - Liberalna demokracija Slovenije / Liberal Democrats of Slovenia

KSS PERGAM - Konfederacija sindikatov Slovenije Pergam / Confederation of Trade

Unions of Slovenia PERGAM (trade unions in paper and graphics industry) 
SDS - Socialdemokratska stranka Slovenije, now: Slovenska demokratska stranka / Social Democratic Party of Slovenia, now the Slovenian Democratic Party

SKEI - Sindikat kovinarstva in elektro industrije / Trade Unions in Metal and Electrical Industry

ZLSD - Združena lista socialnih demokratov, now: Socialni demokrati / Associated List of Social Democrats, now the Social Democrats

ZSSS - Zveza svobodnih sindikatov Slovenije / Association of Free Trade Unions of Slovenia 